\title{
International Law, Western States, Third World States, and the Principles of Right to Economic Self-Determination
}

Brian-Vincent Ikejiaku*

https://doi.org/10.21827/GroJIL.7.2.195-215

\section{Keywords}

INTERNATIONAL LAW; GLOBAL LAW; PRINCIPLES OF ECONOMIC SELFDETERMINATION; HUMAN RIGHTS; WESTERN STATES; THIRD WORLD STATES; INTERNATIONAL (ECONOMIC) LAW AND DEVELOPMENT

\begin{abstract}
In practice, international law appears to have worked against those principles that accord the people of a State the right to economic self-determination, such as the principle of free choice in economic development. This paper argues that the exercise of the right to economic selfdetermination (particularly economic development freedom or free economic development) has been hampered, and has not been freely pursued in practice by developing countries, due to hegemonic control, economic exploitation and domination by the 'powers that be' within the international system. This research examines those principles of international law that accord the peoples of a State the right to free economic development, both in theory and practice; it also provides insights into legal policy implications and the prospects of international law in this area. This paper utilises the well-being and liberal-economic legal theoretical approaches, and interdisciplinary and critical-analytical perspectives, within the framework of international economic law and development.
\end{abstract}

\section{Introduction}

The right to economic self-determination (ES-D) is one of the international legal principles which suggests that the peoples in a sovereign State, within the realm of international law, are independent and free in pursuing their economic development. ${ }^{1}$ The Western States, or

\footnotetext{
Dr. Brian-Vincent Ikejaiku is a joint Director of Post Graduate Law Studies and Research Associate at the Centre for Trust, Peace and Social Relations (CTPSR) at Coventry University, United Kingdom. He was appointed as a visiting Professor of International Law to the European College of Business in mid-2016. Ikejaiku's expertise is International Law and Global Development, particularly international development law and international law, global North and global South. The author thanks the Coventry Law School and Global Research Group at CTPSR and acknowledges the comments of one Professor at Warwick, a leading expert in the field, on the final draft.

1 The author is critical of the (recent) polarised debate within international law and distinction among some scholars, practitioners and States of the global North, between economic self-determination as a right of peoples (as in the International Covenants on Human Rights) and economic sovereignty as a right of States (eg in the NIEO resolutions) and the distinction between the right to development as a human and peoples right versus a State right. The discussion in international law as conceived in this paper is fundamentally about sovereign States and the rights of economic self-determination as those rights 'supposed' to be exercised by people of sovereign States (thus, the people of a sovereign State cannot be separated from a sovereign State itself). The right is seen as affording a framework for the struggle of developing countries to attain the economic independence (as sovereign States and peoples of sovereign States, not struggle within the sovereign
} 


\section{International Law, Western States, Third World States, and the Principles of Right to Economic Self-Determination 196}

countries of the global North, are more developed economically, politically, legally, and industrially than developing third world States of the global South. ${ }^{2}$ The former were not only accorded the right to ES-D, but are free to exercise these rights in practice in order to pursue

States by their peoples) which has not followed automatically upon the attainment of political independence. Thus, any distinction or polarised debate is simply aimed at weakening the legal concept(s) as a useful analytical-critical tool in the context of developing countries. Just as Carthy argues, '[v]arious formulations of the right of peoples to pursue their economic development, whether they are found in the UN Human Rights Covenants, the 1970 Declaration on the Principles of Friendly Relations among States, or the Charter of Economic Rights and Duties of States, to mention only three, present a common theme; a virtually obsessive repetition of the right of economic self-determination. The right is seen as affording a framework for the struggle of developing countries to attain the economic independence which has not followed automatically upon the attainment of political independence. The survival of a legal concept must depend upon its usefulness as an analytical-critical instrument. Now it appears that, in practice, particularly at the United Nations, the claim States make to a right to economic self-determination serves primarily as an ideological representation. Alongside the opposing "Western" claims for the principle of acquired rights and for "pacta sunt servanda", it expresses a real economic contradiction and serves as a banner to mobilize developing countries in the context of a North-South confrontation. Yet such an ideological use of apparently legal concepts does not permit them to function as positive rules of law'. See Anthony Carthy, 'From the Right to Economic Self-Determination to the Rights to Development: A Crisis in Legal Theory' (1984) 3 Third World Legal Studies 73; this equally agrees with the position of Ibhawoh that '[t]he polarized debate amongst states, scholars, and practitioners over the right to development is underlined by salient paradoxes and contradictions. The rhetoric of the right to development has been deployed both as a language of resistance to oppose a hegemonic global economic system and as a language of power to assert national sovereignty and legitimize statist political and economic agendas. Apart from bedeviling the elaboration and implementation of the right to development, the insular political and ideological jockeying that has characterized the discourse raises pertinent questions about the normative objectivity of the international human rights movement'. See Bonny Ibhawoh, 'The Right to Development: The Politics of Polemics of Power and Resistance' (2011) 33 Human Rights Quarterly 77; also Aral suggests that notions like 'positive discrimination' and the 'right to development' still underlie much of the debate between the third world and the West in international forums, such as the UN and the WTO; see Berdal Aral, 'An Inquiry into the Turkish "School" of International Law' (2005) 16(4) European Journal of International Law 769; in order to highlight and critique these contradictions, the author, therefore, uses terms such as 'self-economic determination' and 'economic self-determination' interchangeably; also, terms such as 'free choice of economic development system', 'economic development freedom', 'free economic development', and 'independent economic development' as referring to the same principles (the right to development of peoples of sovereign States in developing countries). When people of an independent sovereign State, in particular developing countries (in the realm of international law), are demanding economic self-determination, what they are invariably asking for is the right of peoples to economic development freedom.

2 For example, in legal trends, the USA and Britain still strongly influence undertakings in the international legal regime; see RP Anand, International Law and Developing Countries: Confrontation or Cooperation (Kluwer Academic Publishers 1987); in economic trends, significant developments since the 1980s show the virtual collapse of the market value of the natural resources extracted from the territories of developing countries and the continued triumph of Western owned multinational corporations (MNCs, which control processing); see Anthony Carthy, 'The Concept of International Development Law' (2008) 1 International Sustainable Development Law; under political trends, Western countries' occupation of most of the strategic positions in global organisations such as the UN (including wielding 'veto power') as well as in other international organisations or agencies; Westerners, particularly the US and Britain have been able 'to influence the political development of states around the world... In many of their colonies, conquests, and clients, they have propagated ideals and institutions conducive to democratization'; see Kevin Narizny, 'Anglo-American Primacy and the Global Spread of Democracy: An International Genealogy' (2012) 64(2) World Politics 341. 
their economic development even at an international level. ${ }^{3}$ This, in effect, allows Western States to pursue their goals of economic development, taking into consideration their domestic distinctiveness. This has therefore placed them in a better position to assert and project their domestic economic interests within the international community of nations in the current globalising world. ${ }^{4}$ The West, for example, particularly the USA and Britain, have advanced economic systems and have been able to influence the economic development of States around the world, including through the use of such economic programmes as liberal economic policies and structural adjustment programmes (SAP). ${ }^{5}$ This is not the case for developing countries of the global South where the principles of ES-D appear to have been recognised more in principle than in practice, as this paper will demonstrate.

The major thrust and argument of this paper is that the exercise of the right to ES-D has been hampered and has not been freely pursued in practice by poor developing countries due to hegemonic control, economic exploitation and domination by the 'powers that be' (particularly the USA and Britain) within the international system. The paper does not suggest that third world States have not benefitted from the international legal regime, but posits that these benefits have been minimal because they have not been permitted to exercise their rights to ES-D freely, due to the hegemonic control of Western States.

The lessons of economic history, in the West, the East and most recently the breakthroughs in the Far East (eg China, South Korea and Singapore), suggest that socioeconomic transformation in terms of rapid economic growth is a prerequisite for political participation and political development. ${ }^{6}$ In effect, economic development goals in third world States, since their independence, have failed to take proper consideration of domestic interests and indigenous needs (eg customs and beliefs, traditional ways of life and artefacts) of the people in society. In agreement with this view, Chatterjee submits that colonial rulers regarded

3 The West has the right to economic development by nature of their superior and dominant position in both international legal regimes and global political economy (that is to say, they discriminately accorded this right onto themselves). For a good illustration, see Narizny (n 2).

4 In this paper, the term 'developing countries' will be used interchangeably with other terms such as 'third world States' or 'global South'; similarly the term 'developed countries' will be used interchangeably with other terms such as 'Western States' or 'global North'. See Brian-Vincent Ikejiaku, 'International Law, International Development Legal Regime and Developing Countries' (2014) 7(1) Law \& Development Review 131.

5 Some may argue that SAP is the policy of the international financial institutions (IFIs such as IMF and the World Bank), but the question is, which countries control or dictate to the IMF. Following an ideology known as neoliberalism and spearheaded by these and other institutions known as the Washington Consensus (for being based in Washington DC and controlled by the West), SAPs have been imposed to ensure debt repayment and economic restructuring. But the way this has happened has received high criticism, as it required poor countries to reduce spending on matters such as health, education and development, while debt repayment and other economic policies have been made the priority. 'Debt is an efficient tool. It ensures access to other peoples' raw materials and infrastructure on the cheapest possible terms. Dozens of countries must compete for shrinking export markets and can export only a limited range of products of Northern protectionism and their lack of cash to invest in diversification. Market saturation ensues, reducing exporters' income to a bare minimum while the North enjoys huge saving. The IMF cannot seem to understand that investing in ... [a] healthy, well-fed, literate population ... is the most intelligent economic choice a country can make' Susan George, Fate Worse Than Debt (Grove Weidenfield 1990) 143, 167, 235.

6 Brian-Vincent Ikejiaku, 'The Concept 'Development' Revisited towards Understanding: in the Context of Sub-Saharan Africa' (2009) 2(1) Journal of Politics and Law 31, 35. 


\section{International Law, Western States, Third World States, and the Principles of Right to Economic Self-Determination 198}

native conditions as uncivilised and as requiring improvement, while forbidding citizenship and the attendant rights of self-improvement to colonial subjects. ${ }^{7}$

It can be suggested that certain fundamental principles of international law necessary to meet independent development or economic freedom, as well as political, social and cultural systems in developing countries, in accordance with the will and needs of their populations, have been interfered with since the 1960s. This was when the majority of the developing countries, particularly those in Africa, gained their political independence. ${ }^{8}$ It is from this perspective that some authors see 'development' as a euphemism for Western penetration and domination of the world, involving great misery and exploitation, both past and present. ${ }^{9}$ This position can be given credence with notable examples, such as Stanley Diamond's frontal attack on a concept associated with development and progress, ie 'civilisation'. Diamond argues that processes of civilisation have always involved conquest, violence, coercion and oppression with respect to so-called less civilised peoples. ${ }^{10}$

The aim of this paper is to examine the international legal principles of ES-D and how these principles have worked in practice within the international system. The right of a State to freely choose its economic system was introduced in the Declaration of Principles of International Law concerning Friendly Relations and Cooperation among States as a component of sovereign equality. ${ }^{11}$ The principles are devoted to the subject of free economic development, which is the right of every country to adopt the economic and social system that

7 Partha Chatterjee, The Nation and its Fragmentation (Princeton 1993).

8 See for example the works of RP Anand, International Law and Developing Countries: Confrontation or Cooperation (Kluwer Publisher 1987); Antony Anghie, Imperialism, Sovereignty and the Making of International Law (Cambridge University Press 2004); BS Chimni, 'International Institutions Today: An Imperial Global State in the Making' (2004) 15(1) European Journal of International Law 1; Brian-Vincent Ikejiaku, 'International Law is Western Made Global Law: The Perception of Third World Category' (2014) 6(2-3) African Journal of Legal Studies 337; Balakrishnan Rajagopal, International Law from Below: Development, Social Movements and Third World Resistance (Cambridge University Press 2003). TWAILERS are scholars, mostly from developing countries, who pursue the international scholarship 'Third World Approach to International Law (TWAIL)', in order to address the injustices against the third world due to the hijacking of international law by Western developed countries.

9 See Andre Gunder Frank, Latin America: Underdevelopment or Revolution (Monthly Review Press 1969).

10 See Stanley Diamond, In Search of the Primitive: A Critique for Civilisation (Transaction Publishers 1974). For instance, the Native Americans have been victims of Western penetration into North America, the slaves have been victims of Western penetration into Africa, and the Inuit have been victims of the spread of Western culture to Alaska. Yet, Diamond does not restrict himself to the results of Western expansion in the world. Wherever people try to spread their civilisation, the fire and the sword are always involved, whether it concerns the expansion of the Greek, the Roman, the Egyptian or the Islamic civilisations. Such criticism is valuable, though at times one-sided. First, it creates an awareness of the costs involved in development. Secondly - and perhaps most importantly - it brings to our attention the relation between the 'concept of development' and international power relations. What one understands by 'development' in a particular historical period is strongly influenced by the dominant cultures and powers of that period. See also Adam Szirimai, The Dynamics of Socio-Economic Development: An Introduction (Cambridge University Press 2005).

11 See Robert Rosenstock, 'The Declaration of Principles of International Law Concerning Friendly Relations: A Survey' (1971) 65(5) The American Journal of International Law 713. See also United Nations General Assembly Resolution 2625 (XXV), 'Declaration on Principles of International Law concerning Friendly Relations and Co-operation among States in accordance with the Charter of the United Nations' (24 October 1970) UN Doc A/Res/2625(XXV). 


\section{9}

GroJIL 7(2) (2020), 195-215

it deems most appropriate for its own development. These are elaborated in several important international legal instruments, such as Article 1 of the Charter of Economic Rights and Duties of States. ${ }^{12}$ Similarly, they are contained in the United Nations (UN) General Assembly Resolution 3201 and the Declaration on the Establishment of a New International Economic Order (NIEO). ${ }^{13}$

This paper argues that the exercise of the rights to ES-D has been hampered and has not been freely pursued in practice by poor, developing countries due to hegemonic control, economic exploitation and domination by the 'powers that be' within the international system. ${ }^{14}$ In essence, international law in practice appears to have worked against those principles of international law that accord States the right to ES-D, such as the freedom of economic development. The trend of events in the international system suggests that the attempts of newly independent developing countries to reconstruct a NIEO in a manner that would benefit their economic development, from the 1960s until the present day, in accordance with these principles of ES-D, has been confronted with difficulties. This is due to actions of the 'powers that be' within the international system, ie the hegemonic activities of Western States and multinational corporations (MNCs); for example, their liberal economic internationalisation policies (a good example is the liberal economic policy of SAP in Africa) ${ }^{15}$ and the immigration policies of developed countries (a good example is the UK's deportation policies that negatively impact the economic development of poor developing countries), as will be discussed in the course of this paper.

The manner through which developing countries have been prevented from exercising their rights accorded by the international legal principle of ES-D has been subtly manipulated in the international system. This is due to the extent to which developing countries have been perceived as not having international legal personality from the outset and their lack of willpower and capabilities for economic development. This submission is captured in Gathii's view: since the third world States were assumed not to have personality in international law, their interests $a b$ initio have continued to suffer because they did not have a role to play in shaping the norms of the earlier international legal order. ${ }^{16}$ This has, to a great extent, been influencing the present international legal order, particularly in the realm of the economic development freedom of third world States. This paper therefore attempts to examine those principles of international law that accord sovereign States the right to freedom of economic development and how these principles work in practice. The paper also intends to make insights into legal policy implications and the prospects of international law and economic development in this area.

12 Charter of Economic Rights and Duties of States, UNGA Res 3281 (XXIX) (12 December 1974) (adopted by 115 votes to $6 ; 10$ abstentions) art 1 .

13 UNGA 'Declaration on the Establishment of a New International Economic Order' UN GAOR 6th Session Supp No 1 UN Doc A/RES/3201(S-VI) (1974).

14 See for example notes 2 and 3 above.

15 ibid; see also Brian-Vincent Ikejiaku, 'The Role of Law and the Rule of Law in Economic Development Process: Quest for New Direction and Approach in the International Development Law Regime' (2019) 47(1) Denver Journal of International Law and Policy.

16 See James Thou Gathii, 'International Law and Eurocentricity' (1996) 9 European Journal of International Law 184; James Thou Gathii is the Wing-Tat Lee Chair in International Law and Professor of Law in the Loyola University Chicago. He is a founding member of the Third World Approaches to International Law network. 


\section{International Law, Western States, Third World States, and the Principles of Right to}

Economic Self-Determination 200

In terms of method, this paper uses the well-being and liberal legal theoretical approaches, interdisciplinary and critical-analytical perspectives within the framework of international economic law and development. It employs qualitative empirical evidence from both developed and developing countries for illustrative analysis. The structure of this paper is in five broad sections. Section 1 is a general introduction. Section 2 considers those principles of international law that accord States the right to freedom of economic development. Section 3 briefly looks at the well-being and liberal-economic legal theories used in the analysis. Section 4 considers how those principles work in practice within the context of the global South and global North (including the issues of SAP and immigration deportation policies). Section 5 covers the author's recommendations by making insights into implications of legal policy, the prospects of international law and the right to economic development freedom.

\section{The Right to Economic Self-Determination}

The international legal principles of ES-D primarily centre on the rights of all peoples of a State, under international law, to freely determine their political and legal status and pursue their own social, economic and cultural development. ${ }^{17}$ This paper focuses on the right of peoples of a State to free economic development. This right, which was later introduced in the Declaration of Principles of International Law concerning Friendly Relations and Cooperation among States as a component of sovereign equality, is elaborated in several important international legal instruments dating back to around 1945. References to a right to development were made as early as the process leading to the adoption of the 1948 Universal Declaration of Human Rights. ${ }^{18}$ The first comprehensive discussion of the right to development as a human right is attributed to Keba M'Baye. ${ }^{19}$ While, for many decades, this fundamental principle has been overshadowed by three other key forms of self-determination, international instruments have recognised and coherently pronounced peoples' right to ESD. ${ }^{20}$ However, the human rights movements as professed under these Covenants and Charter largely failed to exploit and make the most of this clear language. ${ }^{21}$ This right of ES-D is also reiterated and embodied in more recent international instruments, such as the Charter of Economic Rights and Duties of States (General Assembly Resolution 3281 (XXIX) 1974), which in Article 1 provides, inter alia:

17 See Alice Farmer, 'Towards a Meaningful Rebirth of Economic Self-Determination: Human Rights Realisation in Resource-Rich Countries' (2007) 39 NYU Journal of International Law \& Politics 417.

18 See Karin Mickelson, 'Rhetoric and Rage: Third World Voices in International Legal Discourse' (1998) 16(2) Wisconsin International Law Journal 353, 374.

19 ibid 375.

20 See International Covenant on Economic, Social, and Cultural Rights (adopted 16 December 1966, entered into force 3 January 1976) 99 UNTS 171 art 1(2); International Covenant on Civil and Political Rights (adopted 16 December 1966, entered into force 23 March 1976) 999 UNTS 171 art 1(2) (featuring identical articles that state 'all peoples may, for their own ends, freely dispose of their natural wealth and resources...'); African Charter on Human and Peoples' Rights (adopted 27 June 1981, entered into force 21 October 1986) 21 ILM 59 arts 20-21; Alice Farmer, 'Towards A Meaningful Rebirth of Economic SelfDetermination: Human Rights Realisation in Resource-Rich Countries' (2006) 39 New York University Journal of International Law \& Politics 417.

21 ibid. 
Every State has the sovereign and inalienable right to choose its economic system, as well as its political, social and cultural systems in accordance with the will of its people, without outside interference, coercion or threat in any form whatsoever. ${ }^{22}$

Similarly, UN General Assembly Resolution 3201, the Declaration on the Establishment of a New International Economic Order, ${ }^{23}$ was devoted to the subject of free economic development, the right of every country to adopt the economic system that it deems most appropriate for its own development.

The developing countries made dogged attempts, with full commitment and determination, to have the NIEO embodied in international law, but this was subtly, yet vehemently, thwarted by Western States. ${ }^{24}$ The concept of NIEO was coined in the mid-1960s by a group of French academic lawyers who promoted an international law for development'. ${ }^{25}$ This was conceived not as a distinct ambit of international law but as a novel perspective within the whole body of law that centres on international development. However, it was the failed attempt to have the NIEO enshrined in international law that subsequently unfolded into a quest on the part of developing countries for recognition of a right to development as a fundamental human right. Western States have refused to accept such a collective right, which would seem to suggest corresponding duties on their part. In 1986, the UN General Assembly adopted the Declaration on the Right to Development. ${ }^{26}$ The Declaration of the 1993 Vienna Human Rights Conference proclaimed the right to

22 Charter of Economic Rights and Duties of States, UNGA Res 3281 (XXIX) (12 December 1974) (adopted by 115 votes to 6 ; 10 abstentions) art 1; see also Mohammed Bedjaoui, International Law: Achievements and Prospects (Martinus Nijhoff Publishers 1991) 599.

23 UNGA 'Declaration on the Establishment of a New International Economic Order' UN GAOR 6th Session Supp No 1 UN Doc A/RES/3201(S-VI) (1974).

24 Shirley Scot, 'International Law and Developing Countries', The International Studies Encyclopedia (Blackwell Publishing 2010).

25 The NIEO was announced by the G77 in the 1973 Algiers Declaration and was promoted within the United Nations Conference on Trade and Development and the UN General Assembly. UNGA 'Declaration on the Establishment of a New International Economic Order' UN GAOR 6th Session Supp No 1 UN Doc A/RES/3201(S-VI) (1974) and UNGA 'Programme of Action on the Establishment of a New International Economic Order' UN GAOR $6^{\text {th }}$ Session Supp No 1 UN Doc A/RES/3202 (S-VI) (1974) were the products of a special session of the General Assembly devoted to the subject. As set out in the Declaration, changes to the international economic order were to be based on a set of principles including: sovereign equality of states, self-determination of all peoples, inadmissibility of the acquisition of territories by force, territorial integrity and non-interference in the internal affairs of other states; full and effective participation on the basis of the equality of all countries in the solving of world economic problems in the common interest of all countries; the right of every country to adopt the economic and social system that it deems most appropriate for its own development; full permanent sovereignty of every state over its natural resources and all economic activities; regulation and supervision of the activities of transnational corporations by taking measures in the interest of the national economies of the countries where such transnational corporations operate on the basis of the full sovereignty of those countries; preferential and non-reciprocal treatment for developing countries, wherever feasible, in all fields of international economic cooperation whenever possible; giving developing countries access to the achievements of modern science and technology, and promoting the transfer of technology and the creation of indigenous technology for the benefit of the developing countries. See Scot (n 24). See also Mohammed Bedjaoui, Towards a New International Economic Order (Homes \& Meier Publishers 1979).

26 UNGA Res 41/128 (4 December 1986) UN Doc A/RES/41/128. 


\section{International Law, Western States, Third World States, and the Principles of Right to}

Economic Self-Determination 202

development to be a 'universal and inalienable right and an integral part of fundamental human rights. ${ }^{27}$

The difficulty is that Western States are no doubt aware that the right to development is, and should be seen as, one of the universal fundamental human rights. However, they were reluctant to allow poor, developing countries to practically exercise these rights, including the right to ES-D, or to assert it in any other form such as through a NIEO. Therefore, Western States decided to put aside the right to economic development as conceived by the poor countries of the global South and instead concentrate their works and efforts on developments within the field of international law and development that have actually taken place over the last half a century. While the name has been changed over time (by the West, particularly the USA and the UK), it remains the same in its initiatives and purposes. During the 1960s and 1970s, as we have seen, it was known as the 'law and development movement'. ${ }^{28}$ In the 1980s, it was commonly referred to as the 'good governance programme'; it metamorphosed into the 'rule of law and development' in the 1990s and, at the end of the $20^{\text {th }}$ and beginning of the $21^{\text {st }}$ centuries, it had taken up the term 'sustainable development' which has become common parlance. ${ }^{29}$ The concept of sustainable development was borne from the tension between the developed and developing countries. ${ }^{30}$ The doctrine of sustainable development has become a convenient tool for the developed world to undermine the developing world's primary demand of the right to free development, as conceptualised by the principles of ES-D, NIEO and the UN Declaration on the Right to Development. By capturing the development concerns of the developing world within the concept of sustainable development, the agreement between the Western States and third world States has gained validity and justification without any legal devotion to the development efforts of the developing countries. ${ }^{31}$ The Western countries have been using and working through the auspices of sustainable development to further hamper the developing countries' efforts towards achieving free economic development. ${ }^{32}$ For

27 Scot (n 24); see also FV Garcia-Amador, The Emerging International Law of Development: A New Dimension of International Economic Law (Oceana Publications 1990) 18.

28 See further David Trubek and Marc Galanter, 'Scholars in Self-Estrangement: Some Reflections on the Crisis in Law and Development Studies in the United States' (1974) Wisconsin Law Review 1062.

29 See Matthew Stephenson, 'A Trojan Horse Behind Chinese Walls?: Problems and Prospects of US Sponsored "Rule of Law" Reform Projects in the People's Republic of China' (2000) Harvard University Centre for International Law, Working Paper 5-12 no 47.

30 Inherent in the concept of sustainable development was the tension between the competing goals of environmental protection and economic development and, in an international community consisting of a disparate group of States, the tension between the goals of developed and developing states. See Najeeb AlNauimi and Richard Meese, International Legal Issues Arising under the United Nations Decade of International Law (Martinus Nijhoff Publishers 1995). Furthermore, '...the earth is under a two-fold attack from human beings - the excessive demands and wasteful habits of affluent populations of developed countries, and billions of new mouths born in the developing world who (very naturally) aspire to increase their own consumption levels'; see Paul Kennedy, Preparing for the Twenty-First Century (Vintage 1994) 23.

31 Upendra Acharya, 'Is Development a Lost Paradise? Trade, Environment, and Development: A Triadic Dream of International Law' (2007) 45(2) Alberta Law Review 401.

32 In fact, one of the vexing issues regarding the Rio +20 was the concern of many developing countries that the high visibility that is given to SDGs might drive the 'original MDG targets and indicators into obscurity, and would like to see a better manifestation of how the MDGs and SDG will integrate' Francois Mancebo and Ignacy Sachs, Transitions to Sustainability (Springer 2015). 
example, 2015 marked the target date for the realisation of the aim to eradicate poverty, improve people's lives (particularly in developing countries) and rapidly transition to a lowcarbon, climate-resilient economy. Yet, 2015 has come and gone (even though there has been progress, this has been minimal) $)^{33}$ and the quest for ES-D heightens. The UN, championed by Western States, has in 2015 set a new agenda, the 2030 Agenda for Sustainable Development. ${ }^{34}$ Some scholars of international law have been critical of the role of developing countries in this process because sustainable development as a complete conception of the West did not capture the developing countries' ideas of ES-D or those professed by the NIEO. ${ }^{35}$

\section{Legal Theoretical Approaches}

At this juncture, it is helpful to consider relevant legal theoretical approaches that will assist in the examination and understanding of the principles of ES-D and how it applies in practice. This paper applies the well-being and liberal legal theories. On one hand, the liberal legal theory explains how the Western States construct and control development undertakings in developing countries; on the other hand, the well-being theory helps us to understand what would have been the true state of things if the Western States had allowed the rights and principles of ES-D to work for developing countries in practice.

\subsection{Liberal Legal Theory}

Liberalism (and realism) emerged from the distinct belief that is fundamental within the global plane; ${ }^{36}$ this was based on their perceived expectations of the identity of major actors within

33 This is through the UN programme of Millennium Development Goals (MDGs). It has been argued that the MDGs have been a great success in many ways. The global extreme poverty rate has been halved and continues to decline. More children than ever are attending primary school. Child deaths have dropped dramatically. About 2.6 billion people gained access to improved sources of drinking water. Targeted investments in fighting malaria, HIV/AIDS and tuberculosis have saved millions. United Nations, 'Economic Growth and Sustainable Development' (UN, 2 July 2015)<www.un.org/en/sections/priorities/economic-growth-and-sustainabe-development/index.html>.

See Mancebo and Sachs (n 32).

36 Most of the works that have been written on the broad subject of liberalism from an international perspective appear to identify three primary versions; see John Ikenberry, 'Liberal Internationalism 3.0: America and the Dilemmas of Liberal World Order' (2009) 7(1) Perspectives in Politics 71; Anne-Marie Slaughter, 'Liberal International Relations Theory and International Economic Law' (1995) 10(2) American University International Law Review 717; the first is attributed to the ideas of Woodrow Wilson and liberals of AngloAmerican countries towards the post-World War international settlement and is more philosophically oriented. This is most importantly the philosophy of Wilson's progressivism, which is the hallmark of liberalism within this period; see Almon Way, 'The Progressive Conservative' (2005) 7 An Online Journal of Political Commentary \& Analysis. The second is the Cold War liberal internationalism of the post-1945 decades. This version is more politically oriented because of the two divergent political ideological views that shaped it; the liberal internationalism of the post-1945 era was influenced by the political ideological wars between the West and the East; see Michael Doyle, 'Liberal Internationalism, Peace, War and Democracy' (Nobelprize, 22 June 2004) <nobelprize.org/nobel_prizes/themes/peace/doyle/> accessed 13 December 2019; the third version is a somewhat post-hegemonic liberal internationalism that has not completely manifested and whose full shape and logic remain uncertain; this version is more economically oriented in its approach due to the economic strategies it employs in order to achieve its hegemonic liberal control 


\section{International Law, Western States, Third World States, and the Principles of Right to}

Economic Self-Determination 204

the international system, the existing relations of those players to State institutions, and the interrelationships among States. ${ }^{37}$ In the early $20^{\text {th }}$ century, liberal order was viewed in the context of the independence of States and the building of an international legal order that strengthened the norms and regulations behind non-intervention and the sovereignty of States. In the early part of the $21^{\text {st }}$ century, the perception of liberal order changed. It became an expanding order notable for its progressively extensive, intricate and complicated arrangements of international cooperation that deteriorated the existing sovereignty of States and redistributed on a global level the sources and basis of political authority. ${ }^{38}$

The primary distinctive aspect of liberal theory is that it allows for a somewhat unacceptable distinction between different types of States based on their existing domestic political set-up and ideological orientation. Evidence suggests a distinctive quality of relations among liberal democracies, including those which attempted to explain the established empirical phenomenon that liberal democracies rarely go to war with one another. ${ }^{39}$ The US was the major champion of the liberal international project in the $21^{\text {st }}$ century although, in different stages, their specific role within the order has differed. It is clear that the ways in which the United States' pre-eminent geographical position has simultaneously facilitated and impeded the operation of an open, rule-based liberal order is a critical aspect shaping the character and logic of liberal order itself. ${ }^{40}$

There is also an optimistic assumption by liberals that powerful States will act with restraint in the exercise of their power and find ways to credibly convey commitments to other States. Throughout decades, liberal internationalists have shared the view that trade and exchange have a modernising and civilising effect on States, undercutting illiberal tendencies and strengthening the fabric of the international community. ${ }^{41}$ Liberal internationalists also share the view that democracies are - in contrast to autocratic and authoritarian States particularly able and willing to operate within an open, rule-based international system and to cooperate for mutual gain. Likewise, liberal internationalists have shared the view that institutions and rules established between States facilitate and reinforce cooperation and collective problem solving. ${ }^{42}$

In an international legal context, liberal theory has been identified as the 'front-end' and the first, indispensable step in any analysis of international law focusing primarily on explaining the substantive content of international interaction. The starting point for explaining why an instrumental government would contract into binding international legal norms, and comply with them thereafter, is that it possesses a substantive interest in doing so.

internationally. This could be seen in the economic strategies adopted to coerce or, rather, integrate, the developing countries into the liberal internationalism of this period. This third version, which has partly manifested as, and aligns with, liberal economic internationalism (LEI) is one of the theories upon which this paper is built.

37 Slaughter (n 36) 5.

38 Ikenberry (n 36).

39 David Schleicher 'Liberal International Law Theory and the United Nations Mission in Kosovo: Ideas and Practice' (2006) 13(2) Tulane Journal of International and Comparative Law; see also Ikenberry (n 36).

40 Ikenberry (n 36).

41 Michael Doyle, 'Kant, Liberal Legacies, and Foreign Affairs' (1983) 12 Philosophy and Public Affairs 205.

42 ibid. 


\section{GroJIL 7(2) (2020), 195-215}

From a liberal perspective, this means that a domestic coalition of social interests that benefits directly and indirectly from regulation of social interdependence is more powerfully represented in decision making than the countervailing coalition of losers from cooperation. ${ }^{43}$

On international economic interaction, liberal theory serves this purpose because it has been employed in legal research to analyse economic interactions and contradictions within the international system. This paper therefore uses liberal theory in analysing the relations between Western States and developing countries on the issue of the right to ES-D. The liberal legal theory explains how Western States construct, control and contradict development undertakings in developing countries.

\subsection{Well-being Theory}

The well-being theory ${ }^{44}$ has extensively featured in, or rather dominated, the 'economic analysis of law' movement in legal scholarship. ${ }^{45}$ The well-being theory generally propounds the idea that the enhancement of people's well-being is a worthy goal for the state to pursue. In order to achieve the enhancement of people's lives in any given society, the well-being theory need not be rigid or elitist and can be sufficiently flexible to respect people's autonomy and allow many paths to achieving a good life. It shows that objectivity cannot be avoided even in consideration of seemingly subjective preferences of well-being in any given society. ${ }^{46}$

The well-being theory further holds that our desires are always directed toward some future state of affairs. We may want our preferences to be fulfilled because we anticipate that their fulfilment will improve our lives, but the problem is that most people are not allowed to have preferences; when they show or have preferences, their autonomy is not respected by those claiming to promote or enhance people's lives.

Well-being as a legal theory is crucial both in theoretical analysis and practical implementation of the right to ES-D. This is because it uses legal requirements that are manifestly relevant for developmental reforms in society, such as the rule of law, substantive freedom of people, social justice, equality, human rights and empowerment. For example, Amartya Sen's call for understanding development not only in terms of gross national product but also 'in terms of the substantive freedoms of people', which marked an important reframing of the legal and policy discourse around economic development, has its ends centred largely on the well-being of people. ${ }^{47}$ The well-being theory helps us to understand

43 Andrew Moravcsik, 'Liberal Theories of International Law' in Jeffrey Dunoff and Mark Pollacks (eds), Interdisciplinary Perspectives on International Law and International Relations (Cambridge University Press 2013).

44 This paper does not intend to engage in a discussion of the divergent theories of well-being, including 'mental state/experimental theories', which state that well-being is wholly determined by individuals' experiences, consciousness or feelings; see Thomas Scanlon, What We Owe to Each Other (Harvard University Press 1998); 'Desire or preference theory' holds that a person's well-being is determined by the extent to which her preferences are fulfilled; see James Griffin, Well-Being: Its Meaning, Measurement, and Moral Importance (Claredon Press 1989).

45 See Eyal Zamir and Doron Teichman (eds), The Oxford Handbook of Behavioral Economics and the Law (Oxford University Press 2014).

46 See Daphna Lewinsohn-Zamir, 'The Objectivity of Well-being and The Objectives of Property Law' (1998) 78 New York University Law Review 1669.

47 Development as Freedom weaves the most important strands of recent thinking on economic development, social justice, and human rights into a coherent vision of a better world. According to Sen, expansion of 


\section{International Law, Western States, Third World States, and the Principles of Right to}

Economic Self-Determination 206

what would have been the true state of things if Western States had allowed the rights and principles of ES-D to work in practice in developing countries.

\section{The Principle of Economic Self-Determination in Practice}

The explosion of economic nationalism in the third world is due to the large economic gap between the former and the Western world, aided and abetted by the US's Wilsonian antiimperialist moralism. It was this that also scuttled the ill-fated Suez adventure of the British and the French in 1956 to prevent Nasser's nationalisation of the Suez Canal. ${ }^{48}$ The doctrine of sustainable development later became a convenient tool for the developed world to undermine the developing world's primary demand of the right to development. This is as conceptualised in ES-D, NIEO and the United Nations Declaration on the Right to Development (UNDRD). Yet, there was no way in which the new nation States in the third world could be thwarted in the assertion of their national sovereignty and/or ES-D against any purported international property rights. ${ }^{49}$

Indeed, what later emerged was the use of international financial institutions (IFIs) by Western States and economic policies which the IFIs proposed to penetrate the economies of developing countries and third world States. This was in the guise of leading them in effecting their right to ES-D and achieving development, by propagating doctrines such as good governance and sustainable development. The Western States and IFIs were guided by the principles of liberalism, particularly liberal economic internationalism. The rationale behind this is that these IFIs and their economic policies will help to reduce the resource gap in Less Developed Countries (LDCs) by improving the trade imbalance and encouraging a net capital inflow, eradicate poverty and improve the economic development of underdeveloped third world States. It is believed that this will subsequently reduce conflict and entrench peace. ${ }^{50} \mathrm{It}$

freedom is viewed, in this approach, both as the primary end and as the principal means of development. Development consists of the removal of various types of unfreedoms that leave people with little choice and little opportunity to exercise their reasoned agency; see Amartya Sen, Development as Freedom (Oxford University Press 1999). In fact, the resulting MDGs focused much academic research in this area towards a more comprehensive understanding of development, one that would recognise economic growth as intrinsically tied to such areas as: environmental sustainability; food security; the reduction of extreme poverty, hunger, and child mortality; access to health and the promotion of education and gender equality; see Biennial Research Conference, Reassessing International Economic Law \& Development: New Challenges for Law and Policy (College of Law Sutton, 2014).

48 Deepak Lal, 'The Threat to Economic Liberty from International Organisation' (2005) 25(3) Cato Journal 503.

49 With anti-imperialist moralism becoming a part of US foreign policy after Wilson, attempts to protect international property, like the ill-fated Suez adventure of the British and the French in 1956 to prevent Nasser's nationalisation of the Suez Canal, were scuttled by the United States. On 26 July 1956, Egyptian President Gamal Abdel Nasser (in spite of Western foreign policy to protect international property rights) was not deterred in asserting the national sovereignty and economic self-determination of Egypt when he announced the nationalisation of the Suez Canal Company, the joint British-French enterprise which had owned and operated the Suez Canal since its construction in 1869. This emphasizes the importance of economic self-determination to developing countries. See Deepak Lal, Reviving the Invisible Hand: The Case for Classical Liberalism in the Twenty-First Century (Princeton University Press 2010).

50 Thomas Biersteker, Dealing with Debt: International Financial Negotiation and Adjustment Bargaining (Westview Press 1993). 
can be argued that these propositions, development patterns and actions are in line with liberal legal theory if, or insofar as, Western States are believed to be the channel through which the third world States will exercise their right to development in order to achieve economic development. However, most of these propositions and development actions have been criticised and many of the practical initiatives and efforts behind development in third world States, as professed by the Western States, have proved unfruitful. ${ }^{51}$

It has been argued that there must be some relevant fundamental principles or rules of international law connecting international development with its underlying assumptions and actions. For example, under international law, rules must have validity, legitimacy and efficacy. This is only possible if they are based on the common consent of virtually all States in the global community. However, sustainable development, as a conception of the Western States, particularly the USA and Britain, was framed in a manner that in reality will benefit Western States. This is because liberal internationalists are dedicated to promoting a liberal world through encouraging the global emergence of sustainable development and democracy. ${ }^{52}$ In most cases, the preferences and development interests of third world States are not considered. Sustainable development thus lacks these rules, particularly the consent of the developing countries, and does not represent, but rather works against, these countries' ideas behind the principles of and rights to ES-D. It is also not in line with the NIEO, as conceived by the third world States. In order for third world States to exercise their rights to development, all the legal principles and rules affecting development should receive the consent or assent of the sovereign and equal States that make up the international legal order; but this is not the case. ${ }^{53}$ This is in line with the well-being theoretical view that in order to achieve the enhancement of people's lives in any given society, there ought to be sufficient flexibility to respect their autonomy and allow many paths to achieving a good life.

Another criticism against the international legal principles of ES-D in practice relates to the types of law and development reforms assumed by the international development law movement championed by the Western States. Reform in this context is said to rest on three premises; first, that development requires a modern legal framework resembling that in the United States; second, that this framework or model establishes clear and predictable rules and third, that the framework can be easily transferred. This is because liberal internationalists aim to achieve global structure and the Western States are said to have the tools (an efficient legal system, mature political culture and economic strength) to achieve this. This criticism highlights the absence of any empirical data connecting law reform with development, as well as the consequent disagreement among reformers over priorities and strategy. ${ }^{54}$ Another

51 For example, the failure of the law and development movement portrays that the norms of international law as packaged in rich Western countries are in most cases in disharmony with the interests of the third world, which mostly consists of poor developing countries. See also I Head, 'Contribution of International Law to Development' (1986) Paper presented at the Fifteenth Annual Conference of the Canadian Council on International Law.

52 See Anne-Marie Slaughter, 'International Law in a World of Liberal States' (1995) 6 European Journal of International Law 503.

53 Anthony Carthy, 'The Concept of International Development Law' (2008) 1 International Sustainable Development Law.

54 Patrick McAuslan and others, 'Law, Governance and the Development of the Market: Practical Problems and Possible Solutions' in Julio Faundez (ed), Good Government and Law: Legal and Institutional Reform in 


\section{International Law, Western States, Third World States, and the Principles of Right to}

Economic Self-Determination 208

criticism is that a particular law and development initiative or reform in one place or State, introduced in or transferred to another State which has different legal, social, political, economic and other circumstances, can hardly work in consonance to produce positive legal and developmental reforms in the second State. This is because reforms targeted at the law will be impacted upon, affected by or surrounded by all the exigencies within the fabric of society, in many cases in unanticipated ways. This criticism reflects the broad recognition that efforts at building or reproducing Western capitalism, democracy and liberal systems in developing countries has met with 'little success'. This does not augur well with the rights of ES-D as conceived by the developing countries..$^{55}$

Notwithstanding these philosophical principles and theoretical views underlining liberalism and the assumptions of liberal economic internationalists, there has never been a time when economic progress in third world States, through exercise of the right to ES-D under the popular international economic liberal movement and sustainable development projects, has been taken seriously. ${ }^{56}$ Rather, the movement, including the liberal economic policies that influence the international economic law regime, are championed and controlled by the Western countries through the auspices of IFIs. They also initiate and implement liberal economic policies and actions that continue to work against the rights to ES-D and promote the underdevelopment of third world States. ${ }^{57}$ As argued above, since third world States were assumed not to have international legal personality, their interests, including the right to development ab initio, have continued to suffer. This is because it is believed that third world States did not have a role to play in shaping the norms of the earlier international legal order. This, to a great extent, has influenced the present international legal order, particularly regarding the pursuit of the right to ES-D by third world States. ${ }^{58}$ In this context, liberal economic internationalisation has been a key instrument used to manipulate the meaning of sovereign States, as well as their well-being. This has been done by reallocating the hitherto sovereign economic powers of developing States to IFIs. This, to a large extent, limits the possibilities of these States to pursue independent, meaningful and self-reliant economic development. ${ }^{59}$ Just as Sornarajah argues, 'the espousal of economic liberalism by the World

Developing Countries (Palgrave Macmillan 1997); Joseph R Thome, 'Land Rights and Agrarian Reform: Latin American and South American Perspectives' in Julio Faundez (ed), Good Government and Law: Legal and Institutional Reform in Developing Countries (Palgrave Macmillan 1997); see also Trubek and Galanter (n 28).

55 See S Robert, The State, Law, and Development (St. Martin 1978); see also Ikejiaku (n 15).

56 Sustainable development has now become dynamic and is more about sustainable security, as can be seen in its current emphasis on security. For example, the amounts of resources and energy being devoted to the war against terrorism in the last ten years has been tremendous. In fact, scholars and practitioners argue that the resources, which were meant to be for development aid, were diverted from the war on poverty, and instead channelled towards the war on terrorism; see Shahrbanou Tadjbakhsh, 'Human Security Report: War and Peace in the 21st Century' (Human Security Centre, 2005) <www.peacecenter.sciencespo.fr/conflicts-ip-st.htm>, and SIPRI statistics in 2001.

57 See Brian-Vincent Ikejiaku, 'Africa Debt Crisis and the IMF with a Case of Nigeria: Towards Theoretical Explanations' (2008) 1(4) Canadian Journal of Politics and Law.

58 See James Gathii, 'International Law and Eurocentricity' (1996) 9 European Journal of International Law 184.

59 BS Chimni, 'Third World Approaches to International Law: A Manifesto' (2006) 8 International Community Law Review 3, 3. 
Bank (WB), the International Monetary Fund (IMF) and the World Trade Organization (WTO) ensure that these institutions will not favour collective rights such as the right to development'. ${ }^{60}$

Most major, powerful policies (eg democracy, the law and development movement, SAP economic policy and poverty reduction strategies) pursued by the West through the auspices of the IFIs, WB and MNCs, were rooted in liberalism, particularly liberal economic internationalisation. These policies diametrically work against the right to ES-D, in order to maintain hegemonic control over third world States. ${ }^{61}$ As argued, the justification of Western States for their actions in third world States was based on their liberal perception that it will help to reduce the resource gap in LDCs, improve trade balance and encourage a net capital inflow, ${ }^{62}$ to eradicate poverty and improve the economic development of underdeveloped States. ${ }^{63}$ Thus, the growing importance of international organisations such as the G7, IMF and WB suggests that the Western emphasis on liberalism is more for their own benefit, rather than for the well-being of the people of the third world States. Such an approach is indicative of the influence of liberal internationalism in the post-Cold War period. ${ }^{64}$ This suggests that the granting of aid and loans to poorer communities, as a means to eliminate hunger and disease in developing third world States, became the primary aim towards which these institutions directed their activities. However, it has been critically argued that these institutions - from the UN and its development agencies to the WB and the IMF - have resolutely placed their faith in the emancipatory qualities of Western modernity and progress. Moreover, they have displayed a distinctly liberal capitalist bias towards the role of the State in the economy: 'the third world States were not expected to intervene in the economy to the prejudice of first world economic interest' ${ }^{65}$ This is contrary to the well-being legal theoretical postulate that the enhancement of people's lives is a worthwhile goal, if their wishes and preferences are to be fulfilled. It is anticipated that the fulfilment of such wishes will improve their lives, however, most people are not permitted to exercise preferences, as can been seen in the exercise of the right to ES-D.

60 Muthucumaraswamy Sornarajah, 'Power and Justice: Third World Resistance in International Law' (2006) 10 Singapore Yearbook of International Law 19.

61 See Brian-Vincent Ikejiaku, 'International Law is Western Made Global Law: The Perception of Third World Category' (2014) 6(2-3) African Journal of Legal Studies 337; see also Narizny (n 2).

62 Biersteker (n 50).

63 Sornarajah (n 60). Most of the Western Colonial States, including the UK, France and Germany, are very critical and practically prevent immigrants from poor developing countries from migrating to their countries in search of greener pastures and better lives; however, during the period of dislocation in the capitalist economic expansion in Europe, some European countries sought expansion externally by force through colonising most of the developing countries where, according to TWAIL scholars, they legitimised their illegal onslaught and acquired extensive wealth through 'exploitation of third world countries'; see R Anand, International Law and Developing Countries: Confrontation or Cooperation (Kluwer 1987); Anthony Anghie, Imperialism, Sovereignty and the Making of International Law (Cambridge University Press 2004); Chimni (n 8); Ikejiaku (n 61); Rajagopal (n 8); I maintain that Western States are expected to reciprocate this gesture by putting up immigration policies that favour poor developing countries.

64 Biersteker (n 50).

65 See Rajagopal (n 8) 35; see also John Renolds, 'International Law from Below: Development, Social Movements and Third World Resistance (Book Review)' (2009) 15 The Palestine Yearbook of International Law 434. 


\section{International Law, Western States, Third World States, and the Principles of Right to}

Economic Self-Determination 210

Arguments have also been put forward that events in third world developing States provide some critical reasons as to why attempts to redress the development problems caused by the denial of the right to ES-D in developing countries have been further compounded. There has been transparent inequality between the Western States and third world States as a result of exploitation and injustice by the former through the encouragement of increased foreign borrowing. This was encouraged by Western States and made possible with liberal economic international policies, which have contributed to the debt crisis in third world States by increasing the resource and development gaps even further. ${ }^{66}$ The project of foreign borrowing was a subtle scheme made to entrap the third world States in what Cheryl Payer succinctly described as a 'debt trap'; ${ }^{67}$ it was not based on the preferences and free consent of the third world States, contrary to the well-being theoretical view. This assertion becomes clearer when it is understood that the project of foreign borrowing has strict conditions. One such conditional tie has been the insistence that the currencies of these countries be devalued. ${ }^{68}$ The application of this condition, for example in Zambia in 1985, Ghana and Nigeria in 1986 and Ghana in 2015 with the issuing of Eurobond in 2007, ${ }^{69}$ suggests that these economies are far from improving. Rather, they have worsened, and fundamental questions about the longterm utility of foreign borrowing are thereby raised. It has worked against the right to ES-D and contrary to the prescription of the well-being theory because it failed to respect peoples' autonomy and could not provide for the enhancement of their well-being and, therefore, was not a worthwhile goal to pursue in third world States. It was therefore another ploy that Western States used to cripple the third world project of ES-D in practice.

It is documented that the developed world contributed to Africa's capital flight. 'The poor countries are constantly de-capitalised and their economies remain largely dependent upon decisions made in New York, London, Paris and other metropolitan centres' ${ }^{70}$ For example, Zarian Mobutu, Abacha and Babangida in Nigeria have a record of embezzlement of more than USD 5 billion each and Kenyan Arap Moi USD 1 billion. ${ }^{71}$ Most of these funds were lodged in foreign banks in Western States through sophisticated financial tools produced and controlled by the West. Therefore, the reason underdeveloped countries could not develop and were subsequently immersed in poverty is that they are subjected to the structure of the international political-economic system. They are further constrained by imbalanced relations dominated by advanced industrialised countries and their multinational cohorts which adopted liberal policies that have worked against the right to ES-D. In addition to the structure of the global political-economic system, there is an implication that corruption of African

66 Ikejiaku (n 57).

Cheryl Payer, The Debt Trap: The IMF and Third World (Penguin Books Ltd 1974).

Bade Onimode, The IMF, the World Bank and the African Debt (Zed Books Publications Ltd 1989).

69 Ed Cropley, 'A Decade After Write-offs, Africa Sliding Back into Debt Trap' Reuters (Johannesburg, 16 September 2015) <reuters.com/article/us-africa-debt/a-decade-after-write-offs-africa-sliding-back-into-debttrap-idUSKCN0RG24220150916> (accessed 13 December 2019).

70 Kalevi Holsti, International Politics: A Framework for Analysis (Prentice Hall International 1995) 11.

71 Razi Azani, 'Profligacy, Corruption and Debt' (Prober International, 10 February 2005) $<$ journal.probeinternational.org/2005/02/10/profligacy-corruption-and-debt/> accessed 15 December 2019. 


\section{GroJIL 7(2) (2020), 195-215}

leaders who have been immersed into the liberal economic international prescriptions affects the economy of African States with serious implications on the well-being of the people.

However, these powerful transnational bodies, which embody free trade liberalism as their governing ideology, impose free market strictures on developing societies against their right to ES-D. Since they are the primary organisations which formalise and institutionalise market relationships, including the international economic legal norms guiding States, they tied and locked peripheral states into involuntary agreements which forced them to lower their protective barriers (eg the General Agreement on Tariffs and Trade (GATT) and the North American Free Trade Agreement (NAFTA)). Therefore, developing countries of the global South were prevented from developing trade profiles which diverge from the model dictated by their supposed 'comparative advantage' and to that effect work against their ES-D. ${ }^{72}$

Supporting evidence can be found in the nature of the obligations accorded to the adoption of the agreements comprising the Final Act of the Uruguay Round of Trade Negotiations, which lacked transparency. There is a clear suggestion that third world States gained little or virtually nothing from the Uruguay Round agreements. ${ }^{73}$ The IMF and the WB, being guided by liberal international economic ideas, made the provision of finance (or, more accurately, 'debt') to the developing societies conditional on their unilateral acceptance of free market rules for their economies, against their right to ES-D. The conditionality of the so-called structural adjustment programme (SAP) in many third world countries. ${ }^{74}$ In Africa, SAP failed the majority of Nigeria, particularly by bringing mass unemployment. ${ }^{75}$ Kenya also continues to express its displeasure at the IMF and the WB for forcing these policy changes upon it. ${ }^{76}$ In the early 1980s, Uganda was shaken by weeks of demonstrations, as industrial workers and students took to the streets to denounce President Miton Obote's IMF-imposed economic programme. In 1990, Matthew Kerokou of the Benin Republic in West Africa was removed from power following a wave of anti-SAP riots. ${ }^{77}$

It is therefore unsurprising, even understandable, that notable scholars, such as Sachs, are critical about these financial institutions and lambaste the IMF and WB for imposing draconian budgets to support SAP, which had 'little scientific merit and produced even fewer results' ${ }^{78}$ It could rightly be argued that it is no coincidence that governments that continued to operate well (eg Botswana) never had to subject themselves to the painful cure of SAP. ${ }^{79}$ The poor countries are therefore constantly de-capitalised and their economies remain largely dependent upon decisions made by Westerners in New York, London, Paris and other metropolitan centres and implemented through the international institutions that operate and

72 B Scot et al, Theories of International Relations (Macmillan Press Ltd 1996).

73 Chimni (n 59).

74 See Onimode (n 68).

75 African Forum on Network and Development, Nigeria: Foreign Debts Stolen Wealth, IFIs and The West, A Case Study (AFRODAD 2007).

76 Peter Wayande, State Driven Conflict in the Horn of Africa (USAID 1997).

77 Sunday Dare, 'Continent in Crisis, Africa and Globalisation' (Dollars and Sense Magazine, July/August 2001) $<$ thirdworldtraveler.com/Africa/Continent_Crisis.html> accessed 15 December 2019.

78 Jeffrey Sachs, The End of Poverty: How Can We Make it Happen in Our Lifetime (Penguin Books 2005) 198.

79 Goran Hyden, Dele Olowu and Hastings Okoth Ogendo (eds), African Perspective on Governance (Africa World Press 2000). 


\section{International Law, Western States, Third World States, and the Principles of Right to}

Economic Self-Determination 212

function under the philosophical tenets of liberalism. ${ }^{80}$ As Chimni agrees, 'the economic and political independence of the third world is being undermined by policies and laws dictated by the first world and the international institutions it controls' ${ }^{81}$ Even the contemporary Poverty Reduction Strategy used by the WB and IMF, in line with the United Nations Sustainable Development Goals, suggests that poverty reduction in developing countries is all about statistics going upwards and downwards. The reality, contrary to the available statistics, is whether populations of developing countries have the resources and capabilities to live a better life with dignity and to participate normally in society.

The activities of these financial institutions, guided by the norms of liberal economic internationalisation, were more or less intended to control development activities in poor, developing societies and thereby deny the people of third world States their right to ES-D ${ }^{82}$ This view becomes apparent when it is understood that the IMF was initially a purely European establishment. During the first period of its existence, the IMF gave the impression of a certain efficiency, as it helped to re-establish the convertibility of European currencies (1948-1957); thereafter, it aided the adjustment of European economies (1958-1966). From 1967 onwards, however, the IMF failed to maintain stability despite the creation of Special Drawing Rights (SDRs). Parity adjustments were numerous after this date: devaluation of the British Pound and the Franc, revaluation of the German Mark and the Yen and the floating of the price of gold are all examples. The adoption of the general system of floating currencies in 1973 may be considered to mark the end of the Breton Woods mandate. At a point, the continued existence of the IMF was called into question. The institution survived by taking on new functions: management of unilateral structural adjustment in developing countries of the global South and, from the end of the 1980s, intervention in many developing countries with the goal of ensuring the re-incorporation of these countries into the international monetary system using the mechanism of liberal economic international policies, which was contrary to the principles of ES-D in practice. ${ }^{83}$ It is also against the postulation of the wellbeing theory.

Imperatively, and drawing from the above revelations, one might be tempted to ask why an institution such as the IMF, which once failed to deliver in Europe, was drafted to take the lead in the economic recovery of Africa and other developing regions. Surprisingly, and as if oblivious to the question of incompetence on the part of the IMF, Western governments moved to implement the recommendations of the institution by granting loans/aid to any third world countries that followed the IMF's economic liberalisation policies, to the detriment of third world States. From this perspective, it can be pointedly contended that one of the biggest stumbling blocks to developing countries' development in modern times is the external debt crisis that existed as a result of the manipulation of the global economic system by the international financial institutions. This is clear in a foreword to Anighie's work:

${ }^{80}$ Holsti (n 70).

81 Chimni (n 59); Professor BS Chimni is an internationally renowned scholar in the area of international law and an erudite TWAIL Scholar. One of his most influential works is BS Chimni, 'Third World Approaches to International Law: A Manifesto' (2006) 8 International Community Law Review 3.

82 Collins Okafor, Neo-Democracy and Poverty Management in Africa (Mercury Bright Press 2004).

83 S Amin, 'Fifty Years is Enough (Part 1)' (1994) 8(2) South African Political and Economic Monthly. 
The newly independent states... fought to develop new rules, even a new international economic order. But in the event the Bretton Woods Institutions triumphed, imposing their own view of development and a certain set of structures of governance on half the world's population and a majority of its governments. The outcome has been, on the whole, increased indebtedness and new forms of dependence. ${ }^{84}$

According to the International Development Forum, the annual expenditure on healthcare in the poorest countries averages less than USD 5 per person. In wealthier countries, such as the USA, France or Canada, health expenditure averages USD 400 per person. ${ }^{85}$ This is because the poor are either entirely unemployed or underemployed. The situation is contrary to the decades before the liberal economic international movement reforms were introduced as part of the sustainable development programme, as the 1997 IMF Report has confirmed. According to that report, in the decade prior to 1985, many third world countries in East Asia, South Asia and sub-Saharan Africa experienced annual growth rates of employment in excess of $5 \%$, with some as high as $10 \%$ per annum. ${ }^{86}$ Again, the administration of loans and aid from developed States to underdeveloped third world States remains economically retrospective.

Other policies, such as various immigration policies in most developed Western States, are aggressive to immigrants from developing countries. For example, the current immigration policies in the UK, implemented by the Conservative government, are aimed at reducing the number of immigrants by all means possible.Most of these immigrants entered the UK legally and work hard in order to reduce the poverty levels in their home countries by sending hardearned money home. The process of renewing their visas in order to remain legal residents is very cumbersome, the reason being to reduce the number of immigrants in the UK. Poverty cannot be reduced in developing countries with a policy of this nature and it works against the right to ES-D. During the period of dislocation in the capitalist economic expansion in Europe, some European countries sought external expansion by force, through colonising most developing countries where, according to TWAIL scholars, they acquired extensive wealth through the 'exploitation of third world countries' ${ }^{87}$ The West (especially the former colonisers) are expected to reciprocate this gesture by adopting policies that favour poor developing countries, in their bid to achieve economic development.

\section{Recommendations}

Despite the role international law has played in the unfair treatment of the people of third world States, the new States did not reject international law in its entirety. Rather, many third world States accepted the treaties and agreements made on their behalf by the former colonial powers, with the belief that they would be able to amend, modify, renegotiate or replace them with the consent of the other parties. However, this has not been possible; for example, third world States stressed sovereignty as a form of protection against military, economic, political or any other form of intervention and, particularly, the denial of their rights to ES-D.

\footnotetext{
84 See Antony Anghie, Imperialism, Sovereignty and the Making of International Law (Cambridge University Press 2004) foreword.

85 Onimode (n 68).

86 ibid.

87 See (n 8).
} 


\section{International Law, Western States, Third World States, and the Principles of Right to}

Economic Self-Determination 214

Developing countries also attempted to develop international legal concepts, principles and organisations that they could use to improve their position in the international order; yet, these have met with little or no success due to opposition from the West. ${ }^{88}$

As resource discovery and exploitation is increasingly seen as a primary means of reinvigorating the economies of poor states, ES-D must be reincorporated into the mainstream human rights dialogue. ES-D gives peoples the ability to take control over their national resources and use those resources as a means for actualising their own ends, that is the improvement of peoples' lives. It is a fundamental norm upon which the realisation of broader rights is based; however, the concept has neither been incorporated nor integrated into advocacy strategies. It is high time for human rights advocates to put that language to use, by bringing ES-D out of the shadows and employing it as a powerful tool for human rights advocacy related to the distribution of wealth from mineral resources. ${ }^{89}$

Moreover, this paper suggests that the people of third world States should be permitted to determine their own destiny, particularly as related to their right to ES-D, in order to achieve the enhancement of their lives, in line with the well-being theory.

Relying on well-being theoretical postulations, the enhancement of people's well-being is a worthy goal for the state to pursue and people's desires are always directed toward some future state of affairs. The theory holds that peoples want their preferences to be fulfilled because they anticipate that their fulfilment will improve their lives, but the problem is that most people, such as those in third world States, are not permitted to have preferences. When they express preferences, their expected autonomy is not respected by those claiming to promote or enhance peoples' lives; that is, the 'powers that be' within the international system. The well-being theory is relevant and manifest for development reforms in society because it recognises vital ingredients that aid development, such as the rule of law, the substantive freedom of people, social justice, equality, human rights and empowerment.

Grounded on the well-being theory, it is the suggestion of this paper that international development projects should recognise and respect the wishes, preferences and freedoms of the peoples of third world States by involving them deeply in any development programmes that concern them. They are more acquainted with the development concerns, priority needs and cultures of their regions. Just as Sen rightly argues, development is 'in terms of the substantive freedoms of people'.$^{90}$ There should, however, still be support from richer Western countries; in UN General Assembly Resolution 2626 of 1970, the UN General Assembly had, after acknowledging that the primary responsibility for the development of developing countries rests upon the developing countries themselves, equally noted that, 'however great

88 RP Anand, 'Attitude of the Asian-African States toward Certain Problems of International Law' (1966) 15 International and Comparative Law Quarterly 55, 70.

89 Scot (n 72).

90 Freedom, in Sen's perception, 'concentrates particularly on the roles and interconnections between certain crucial instrumental freedoms, including economic opportunities, political freedoms, social facilities, transparency guarantees, and protective security. Societal arrangements, involving many institutions (the state, the market, the legal system, political parties, the media, public interest groups and public discussion forums, among others) are investigated in terms of their contribution to enhancing and guaranteeing the substantive freedoms of individuals, seen as active agents of change, rather than as passive recipients of dispensed benefits' Amartya Sen, 'Development as Freedom' (New York Times, 1999)

<nytimes.com/books/first/s/sen-development.html> accessed 13 December 2019); see also Sen (n 47). 


\section{GroJIL 7(2) (2020), 195-215}

their own efforts, these will not be sufficient to enable them to achieve the desired development goals as expeditiously as they must, unless they are assisted through increased financial resources and more favourable economic and commercial policies on the part of developed countries. ${ }^{91}$ To this effect, instead of working against the principles of ES-D, Western States should support the project in developing countries.

\section{Conclusion}

This paper sought to examine the international legal principles of ES-D and how those principles work practically within the international system. The argument of the paper is that the exercise of the right to ES-D has been hampered and has not been freely pursued in practice by poor developing countries due to hegemonic control, economic exploitation and domination by the 'powers that be' within the international system. That is due to the actions of Western States and financial institutions in controlling the development activities of developing countries.

The paper finds that the right to ES-D is recognised only in principle in third world States because the practical and free exercise of the right has been under the hegemonic control of the 'powers that be' in the international system. In effect, economic development goals in third world States, since their independence, have failed to take proper consideration of domestic interests, political and cultural distinctiveness and indigenous needs of peoples in society.

It further demonstrates that, since the 1960s, trends of events in the international system show that the attempts of the newly independent developing countries to pave the way for a NIEO in a way that would be beneficial to economic development in third world States, in accordance with the principles of ES-D, has faced many difficulties and challenges. This is due to the hegemonic actions of the West, IFIs and MNCs based on their liberal underlining.

The paper shows that sustainable development was borne from the tension between the global South and global North. Western States used the doctrine of sustainable development as a convenient tool to subvert third world States' rights to ES-D. By veiling the development concerns of the third world States under the umbrella of sustainable development, agreement between the two worlds was sanctioned without any legal commitment to the development efforts of the developing countries.

In conclusion, relying on the well-being theory as highlighted in this paper, efforts to assert the right to ES-D can only be realised when Western States remove their hegemonic control over third world States. This will allow third world States to make their own decisions that will take into consideration their indigenous needs and enable them to endeavour to recognise the various salient factors that aid development (such as the rule of law, the substantive freedom of people, empowerment, human rights, social justice and equality) and allow them to flourish.

\section{www.grojil.org}

91 UNGA Res 2626 (XXV) (24 October 1970) UN Doc A/RES/2626 (XXV) art 11. 